\title{
SAMUEL BECKETT EN ESPAÑA
}

José Francisco Fernández, ed.

Valladolid: Ediciones Universidad de Valladolid, 2020

\section{INÉS LOZANO-PALACIO}

\section{Universitat Politècnica de València}

ilozpal@idm.upv.es

The reception of Samuel Beckett's literary work in Spain has been an irregular and peculiar one, marked by a combination of factors including the moral resistance to innovation on the part of the Franco regime and the aura of existential anguish surrounding Beckett's work (Harvey 1960; White 1970; Dobrez 1986). Beckett was also read as a political author whose ideas fueled the feeling of oppression and dissatisfaction with the dictatorial regime (see Chapter 3 ). These factors perhaps explain why the attention devoted by Spanish academia to Beckett's work has also been superficial, especially if compared to that received by other contemporary Irish authors such as James Joyce. Samuel Beckett en España comes to the rescue as a relevant and much needed book bringing together chapters on the reception of Beckett's literary work in Spain. The book is structured in ten chapters and addresses a wide variety of topics, ranging from translations of Beckett's theatrical works into Spanish to the censorship imposed on his work by the Franco regime.

Following the editor's preface, which outlines the central aspects of each chapter of the book and places them in a wider research context, the book starts with a chapter by Antonia Rodríguez-Gago on the transculturality of Beckett's language(s), focusing on the theatrical piece Happy Days and how it was staged in Spain at the end of the 90s. Rodríguez-Gago's previous work has focused on this topic, providing preliminary insights that are further developed in this chapter. This author has rightly pointed out that in Spain, Beckett has always been seen as 


\section{Reviews}

an obscure, 'marginal' author, relegated to theatres outside the mainstream (Rodríguez-Gago 2010). The decade of the 1990s was particularly interesting in this regard. As an English-speaking author often presenting his work in French, Beckett's output underwent culture-related linguistic transformations. RodríguezGago's chapter assesses the various transcultural aspects of Happy Days.

In the second chapter, the attention shifts to the Spanish region of Galicia. Manuel García Martínez examines how Beckett's work was received in the Galician context, pointing out the role played by university theatre groups, key in introducing Beckett's theatre in Spain in general and in Galicia in particular. The shared traditions between Galicia and Ireland make this Spanish region a particularly interesting context of analysis. In fact, Beckett himself was involved directly in the staging of A Piece of Monologue at the University of Santiago de Compostela, directed by David Green. This chapter provides a general vision of the Galician political context in the $20^{\text {th }}$ century and of how the cultural bond between Beckett's background and the Celtic traditions in Galicia created a link that was later to be translated in the usage of Beckett's work as a tool for protest against the Establishment.

The third chapter, by Núria Santamaría Roig, takes us to Catalonia, where Beckett's work had a special impact as an emblem of the ideological movement against the Franco dictatorship. In particular, the chapter focuses on the theatre company La Gàbia, which played a major role in bringing Beckett's work onto the stages of a wide variety of Catalonian towns. Translations of the Irish author's works became transgressive icons in the Catalonian theatrical scene. This chapter analyses the archives of La Gàbia and includes insights resulting from Beckett's collaboration with Joan Anguera, co-founder of the company. In spite of its outstanding impact in the cultural and theatrical context, the academic literature on the Catalonian reception of Beckett's work has been scarce. Like Chapter 2, this chapter focuses on how the cultural diversity in Spain has triggered a variety of reactions to Beckett's work.

In Chapter 4, Olaia Andaluz-Pinedo and Raquel Merino-Álvarez provide a panoramic picture of Beckett's theatrical productions throughout the period of the Franco regime, paying special attention to censorship. One of the key ideological pillars of the Spanish dictatorship was certainly literary and artistic censorship, as a way of stifling anti-regime ideological impulses and avoiding challenges to the dictatorial ideology. Samuel Beckett's work underwent severe censorship in a variety of countries (Johnson 2014). However, interestingly, the Spanish dictatorship was not particularly severe with Beckett's work, whose experimental and reflexive nature seemed to distract censors from its underlying content. The analysis carried out by the authors of this chapter, based on the 


\section{Reviews}

General Archives of the Spanish Administration, provides novel insights into censorship drawing from Spanish archive material. Spanish interest in Beckett's work was surprisingly widespread and by no means exclusive to larger cities like Madrid or Barcelona. At all times, however, the regime limited representations of Beckett's work to small theatres and university theatre groups, as previous chapters of this book illustrate.

The fifth chapter provides an overview of four translations of Beckett's Waiting for Godot into Spanish. Translations of Beckett's work into Spanish have previously been addressed by academia (cf. Fernández 2011). However, the novelty of this contribution is the comparison between variants of the Spanish language in conveying the meaning originally intended by Beckett. David Martel Cedrés examines four translations (three of them Spanish and one Argentinian), and concludes that revising these translations is highly insightful. The analyzed translations in many ways ignore the author's original text in either English or French. The author of this chapter carries out a fine-grained comparative study of different textual marks in the four translations, paying special attention to grammatical mistakes and literary license taken by each of the translators.

In Chapter 6, Carlos Gerald Pranger looks at the linguistic import of Waiting for Godot into Spanish. Translations into Spanish have invariably taken the French text as a source and have therefore missed the variations of the English text. This chapter analyses the main losses for the Spanish reader who has not had access to the English references. The author claims that the English text is more precise, colloquial and pungent than the French one. Therefore, the literary voyage of the Spanish reader/spectator is somehow incomplete without the said references. Unlike previous studies on Beckett and translation, this comparative analysis focuses on the source text rather than on the target texts, with the aim of tracing back where the translations come from in order to explain references or expressions that may remain unnoticed.

Chapter 7 shifts to a different genre. Studies on Beckett's work in Spain have mostly focused on his theatrical work. His novels, on the other hand, have mostly remained overlooked. Bringing this genre to the stage, José Francisco Fernández delves into Beckett's novel How It Is (Comment c'est in French), and examines how this work was received in Spain. The conclusion is that, just like the rest of the Irish writer's work, How It Is was regarded as a symbolic text in Spain, hence analyzed through a narrow and partial lens. Fernández's study looks at the main themes and key aspects in the novel. This is of particular interest in order to achieve a closer, more approachable and complete analysis of the text, especially given its cultural relevance. In Chapter 8, Loreto Casado Candelas examines Beckett's work from a francophone perspective. During the Franco regime, French was the predominant foreign 


\section{Reviews}

language in Spanish schools, which not only delayed the entrance of Spain into the anglophone cultural market but also meant French was the main language of literary import. Spain had initially seen Beckett as a dense and somehow obscure author, and French helped redirect this image and provided a closer, more approachable link to his work. Casado Candelas explains the role played by the French language as a vehicle for the transmission of Beckett's work from a Spanish perspective, introducing novel insights into the cultural reasons guiding public opinion during the Franco dictatorship.

Finally, the last two chapters of the book, written by Mar Garre García, comment on a bibliographical database of the academic work on Samuel Beckett published in Spain, each chapter discussing different aspects of the research process and the listed titles. The analysis of this database sheds light on the obstacles faced by Beckett's works in Spain, both with regard to their performance when the texts were imported, and in terms of the scholarly work devoted to them. The bibliographical titles are further classified according to the literary genres involved and the global themes discussed. This is enlightening in many ways, notably as far as the relationship between Spanish history and the reception of Beckett's work is concerned.

The book as a whole provides a highly necessary compilation of studies on the relationship between Beckett's work and the Spanish historical context. As notable and canonical as Samuel Beckett's work has become, for several years it met with many obstacles on the road to being produced on stage in Spain. This affected not only the reception of the theatrical texts, but also of the author's prose (as evidenced in Chapter 7). The cultural and linguistic patchwork that makes up Spain is of particular interest here. The various regions received Beckett's work differently, whilst simultaneously national censorship built a unified set of limitations (as seen in Chapter 4). Among the regions, Galicia, traditionally close to Ireland, and Catalonia stand out in terms of the reception of Beckett's work, as evidenced in Chapters 2 and 3. At the same time, we must bear in mind Beckett's work arrived in Spain in the form of translations. Studying aspects such as the source language of the translations (as in Chapter 6), the transculturality of the translated work (Chapter 1), or the various final products in Spanish (Chapters 7 and 8) sheds light on the reasons guiding the scholarly production on Beckett's work in Spain (Chapters 9 and 10).

The contributions compiled in this volume cover areas of study that have until now remained ignored. The book brings together an array of topics under a single umbrella: providing a holistic and complete picture of the reception of Beckett's work in Spain, delving into regional differences, translation challenges and outcomes or collections of academic work. The only weakness one might point out 


\section{Reviews}

is that the analytical methodology used for the studies collected in this book is not always clear. This minor objection notwithstanding, this is a highly relevant work in the field of Beckett studies.

All in all, the book provides a comprehensive and highly necessary study of the relationship between Samuel Beckett's work and Spain, accounting for its presence and also its absence in different Spanish contexts.

\section{Works Cited}

Dobrez, L.A.C. 1986. The Existential and its Exits: Literary and Philosophical Perspectives on the Works of Beckett, lonesco, Genet and Pinter. London: Athlone.

FernÁndeZ, José Francisco. 2011. “Spanish Beckett". In Losada Friend, María, José MaríaTejedor Cabrera, José Manuel Estévez-Saá and Werner Huber (eds.) Dreaming the Future: New Horizons/Old Barriers in 21 $1^{\text {st }}$ Century Ireland. Trier: Wissenschaftlicher Verlag Trier: 63-74.

Harvey, Lawrence E. 1960. "Art and the Existential in En Attendant Godot." PMLA 75 (1): 137-146.

Johnson, Nicholas. 2014. "A Theatre of the Unword: Censorship, Hegemony and Samuel
BeCKETT". In Collins, Christopher and Mary P. Caulfield (eds.) Ireland, Memory and Performing the Historical Imagination. Houndmills, Basingstoke: Palgrave Macmillan. 36-54.

Rodríguez-Gago, Antonia. 2010. "Staging Beckett in Spain: Theater and Politics". In GontaRSKI, S.E. (ed.) A Companion to Samuel Beckett. Malden, MA: Wiley-Blackwell: 403415.

WHITE, Patricia O. 1970. "Existential Man in Beckett's Fiction". Critique: Studies in Contemporary Fiction 12 (2): 39-49. 